\title{
Interactive comment on "Deep convective influence on the UTLS composition in the Asian Monsoon Anticyclone region: 2017 StratoClim campaign results" by Silvia Bucci et al.
}

Silvia Bucci et al.

sbucci@Imd.ens.fr

Received and published: 20 June 2020

The comment was uploaded in the form of a supplement: https://www.atmos-chem-phys-discuss.net/acp-2019-1053/acp-2019-1053-AC1supplement.pdf

Interactive comment on Atmos. Chem. Phys. Discuss., https://doi.org/10.5194/acp-2019-1053, 2020. 